\title{
Whitening Agent : Mekanisme, Sumber Dari Alam dan Teknologi Formulasinya
}

\author{
Amelia Soyata*, ${ }^{*}$, Anis Yohana Chaerunisaa² \\ ${ }^{1}$ Sekolah Tinggi Ilmu Kesehatan Harapan Ibu Jambi, Prodi Farmasi, Jl. Tarmizi Kadir No 71 Pakuan \\ Baru, Jambi, \\ 2Departemen Farmasetika dan Teknologi Formulasi, Universitas Padjadjaran, Jalan Raya Bandung \\ Sumedang km 21 Jatinangor, Sumedang 45363, Indonesia, \\ ${ }^{*}$ E-mail: amelia18015@mail.unpad.ac.id \\ (Submit 22/6/2020, Revisi 31/7/2020, Diterima 26/2/2021, Terbit 25/4/2021)
}

\begin{abstract}
Abstrak
Sekarang ini adanya keinginan alamiah untuk tampil cantik khususnya pada kaum wanita telah meningkatkan kesadaran tentang pentingnya perawatan kulit dan warnanya, untuk itu upaya yang dapat dilakukan adalah memutihkan kulit dengan menekan produksi melanin menggunakan whitening agent, sehingga dilakukan penulisan artikel review ini dengan tujuan mengetahui jenis-jenis whitening agent, mekanismenya dan penggunaan teknologi formulasinya. Beberapa contoh whitening agent yaitu hydroquinone, ascorbic acid, kojic acid, arbutin, niacinamide, retinoid, azelaic acid, namun beberapa zat ini dapat menimbulkan permasalahan pada kulit seperti iritasi, dermatitis, alergi dan kanker kulit sehingga sekarang ini dapat digunakan whitening agent dari alam yang minim efek samping seperti temulawak, cendana, teripang, dan prunus. Mekanisme utama whitening agent adalah menghambat enzim tirosinasedan, dan untuk memaksimalkan efek whitening pada kulit telah dikembangkan teknologi formulasi menggunakan beberapa metode penghantaran seperti liposom, nanopartikel, solid lipid nanopartikel dan mikroemulsi.
\end{abstract}

Kata kunci: Whitening agent, mekanisme, teknologi formulasi

\section{Pendahuluan}

Kulit merupakan salah satu organ penting bagi tubuh yang terdiri dari beberapa layer termasuk stratum corneum, epidermis dan dermis. Adanya keinginan alamiah untuk tampil cantik khususnya pada kaum wanita telah meningkatkan kesadaran tentang pentingnya perawatan kulit dan warnanya, sebagian besar wanita di negara Asia ingin memiliki kulit yang putih, namun mayoritas penduduk Asia Tenggara memiliki warna kulit yang lebih gelap terutama disebabkan karena paparan harian sinar matahari yang kuat ${ }^{1}$. 


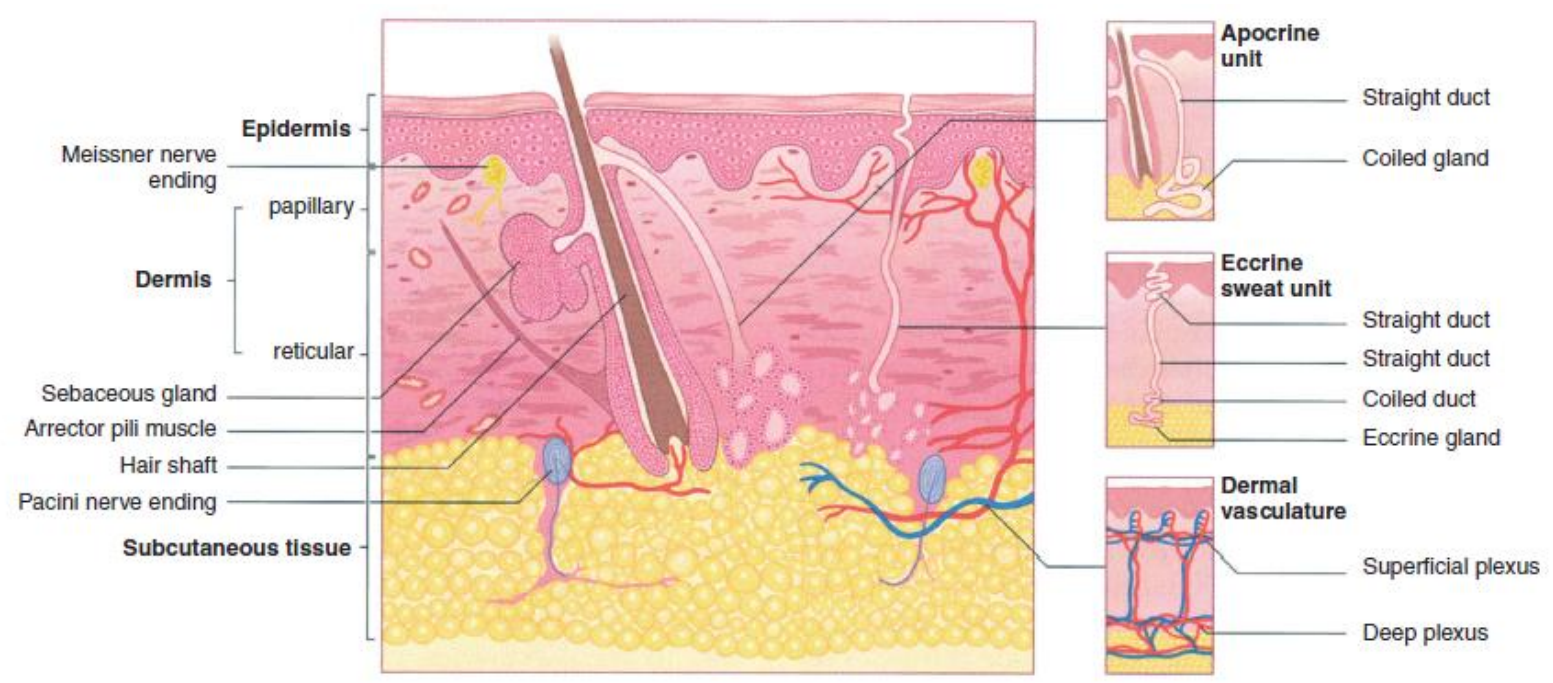

Gambar 1. Struktur Kulit ${ }^{2}$

Penggunaan produk kimia untuk mengurangi hiperpigmentasi kulit yaitu dengan beberapa mekanisme seperti mengurangi konsentrasi melanin yang dikenal sebagai whitening agent. Saat ini mencerahkan kulit adalah salah satu prosedur paling umum untuk meningkatkan pigmentasi pada kulit ${ }^{3}$. Pemutih kulit ini telah banyak menjadi perhatian di bidang kosmetik untuk dikembangkan oleh para peneliti dan industri farmasi, pengembangannya di pasaran sudah ada dalam bentuk sunscreen, cream, ataupun lotion ${ }^{4}$.

Warna kulit seseorang ditentukan oleh melanin, melanin adalah hasil sintesis biopolimer melanosome ${ }^{5}$. Melanin disintesis dalam melanosit di lapisan basal epidermis dengan proses melanogenesis ${ }^{1}$. Melanosom mengandung tiga enzim melanogenic yang spesifik seperti tyrosinase, tyrosinase protein 1 (TRP 1) dan tyrosinase protein 2 atau dopachrone tautomerase $(D c t)^{6}$. Tyrosinase ini merupakan enzim kunci dari produksi melanin yang menjadi target mekanisme kerja dari whitening agent, yaitu dengan menghambat enzim tyrosinase. Contohnya adalah hydroquinone, ascorbic acid, kojic acid, arbutin ${ }^{4}$, sebagian besar bahan aktif ini meringankan warna kulit melalui penghambatan satu atau lebih maturasi atau distribusi melanosit, contohnya kortikosteroid, hidrokuinon, garam monobenzyl hidrokuinon, tretinoin dan merkuri? Namun penggunaan beberapa whitening agent ini dapat menimbulkan efek yang berbahaya terhadap kulit, sehingga sekarang ini banyak digunakan whitening agent dari alam yang minim efek samping.

Karena pentingnya whitening agent dalam bidang kosmetik maka perlu dilakukan pengumpulan informasi lebih dalam tentang whitening agent melalui penelurusan pustaka. Dalam artikel review ini akan membahas mengenai sintesis melanin, contoh whitening agent, mekanisme kerjanya, whitening agent dari alam serta teknologi formulasinya. 


\section{Metode}

Dalam artikel review ini dilakukan penelusuran literatur yang dikumpulkan dari internet melalui google scholar, elsevier, pubmed, dengan menggunakan kata kunci whitening agent, formulation of whitening agent, hydroquinone, melanin, arbutin. Jumlah literatur yang diperoleh sebanyak 115 jurnal, namun yang termasuk ke dalam kriteria inklusi sebanyak 73 jurnal. Adapun kriteria inklusi dalam penulisan artikel ini adalah artikel dengan tahun publikasi $>2000$, tinjauan whitening agent, teknologi formulasi whitening agent.

\section{Hasil dan Pembahasan}

\section{Sintesis Melanin}

Melanogenesis adalah proses sintesis pigmen melanin dalam organel yang terikat membran melanosoma ${ }^{8}$. Melanosom menghasilkan tiga jenis melanin - pheomelanin dan dua jenis eumelanins. Pheomelanin mengandung unit benzothiazole sementara eumelanin terdiri dari bentuk tereduksi dan teroksidasi dari 5,6-dihydoxyindole (DHI) dan 5,6-dihydroxyindole-2- carbo xylicacid (DHICA) bersama dengan cincin pirol ${ }^{9}$. Biosintesis melanin terutama tergantung pada aktivitas tirosinase dan radiasi UV. Tyrosinase memainkan peran penting dan mengambil bagian dalam konversi tirosin menjadi L-DOPA, oksidasi L-DOPA menjadi dopaquinone (DQ) dan dalam transformasi DQ selanjutnya yang mengarah ke produk akhir yaitu melanin. Namun, substrat untuk biosintesis eumelanin dan pheomelanin berbeda. DQ adalah substrat utama dalam sintesis eumelanin tetapi pheomelanin disintesis dari DQ di hadapan sistein ${ }^{9-11}$.

Langkah pertama, secara umum untuk semua jenis melanin, melibatkan hidroksilasi tirosin menjadi 3-4-dihydroxyphenylalanine (L-DOPA) dan oksidasi L-DOPA menjadi dopaquinone. Keduanya dikatalisis oleh tirosinase, enzim penting untuk alur biosintetik melanin ${ }^{8,12,13}$. Ketersediaan substrat dan fungsi melanogenetik enzim menentukan jenis melanin yang diproduksi. Dopaquinone dengan adanya sistein menghasilkan 3- atau 5cysteinyl DOPA dengan oksidasi dan polimerisasi akan menghasilkan pheomelanin kuning/merah ${ }^{9,14}$. Dengan tidak adanya sistein, dopaquinone mengalami siklisasi intramolekul non-enzimatik secara spontan dan pengaturan ulang lebih lanjut, menghasilkan dopachrome. Proses ini terjadi sangat cepat ${ }^{15}$.

Dopachrome menghasilkan eumelanins oleh dua jalur - nonenzymatic dan enzimatic, dengan menggunakan protein terkait tirosin (TRPs). Dalam kasus pertama dopachrome mengalami dekarboksilasi spontan menjadi 5,6-dihidroksiindol (DHI), yang dengan cepat teroksidasi dan terpolimerisasi menjadi gelap coklat/hitam yaitu $\mathrm{DHI}$-melanin ${ }^{15}$. Di jalur kedua TRP2 (DCT, Dopachrome tautomerase) tautomerisasi DOPAchrome 
untuk membentuk DHI- 2-carboxylic acid (DHICA). Selanjutnya, TRP1 mengkatalisasi oksidasi dan polimerisasi DHICA dan membentuk warna coklat, DHICA-melanin (9). Mekanisme sintesis melanin dapat dilihat pada gambar 2. Enzim kunci dalam sintesis melanin adalah tyrosinase (TYR). Transkripsi TYR dikendalikan oleh transkripsi microphthalmia faktor (MITF), pengatur utama melanogenesis. Selain MITF, ada stimulator melanogenik parakrin sebagai hormon perangsang alfa-melanosit (a-MSH), yang dapat memodulasi pigmentasi. Hormon melanotrofik ini bekerja sebagai agonis, ketika berikatan dengan reseptor melanocortin-1 (MC1R), menghasilkan peningkatan pembentukan melanin ${ }^{16-18}$. Cara paling ampuh untuk mempengaruhi sintesis melanin adalah dengan paparan sinar matahariyang menginduksi Reactive Oxygen Spesies(ROS) yang bertindak sebagai sinyal untuk proliferasi melanosit dan melanogenesis ${ }^{14,16,19}$.

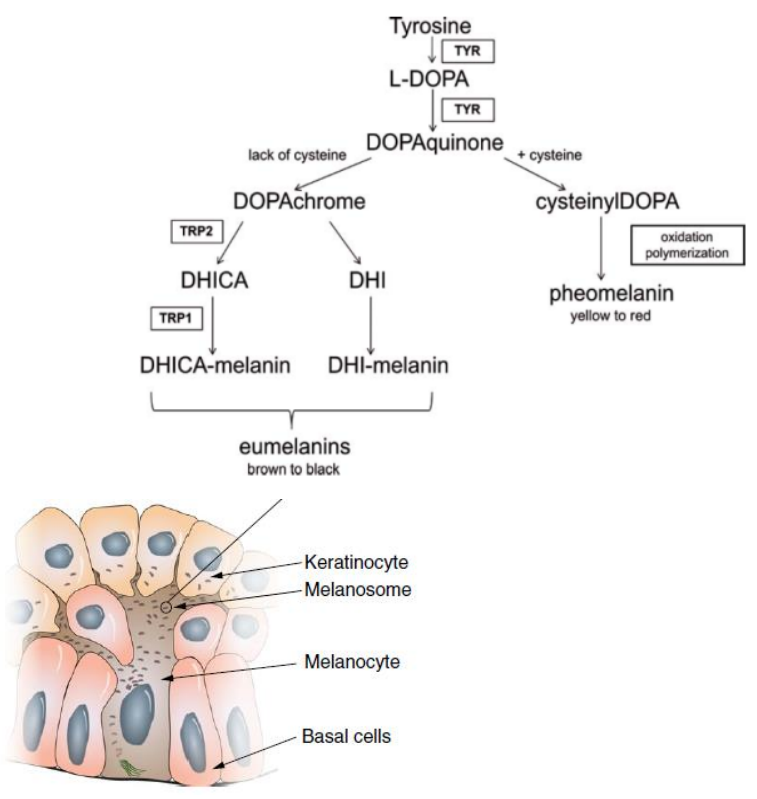

Gambar 2. Mekanisme Sintesis Melanin 20

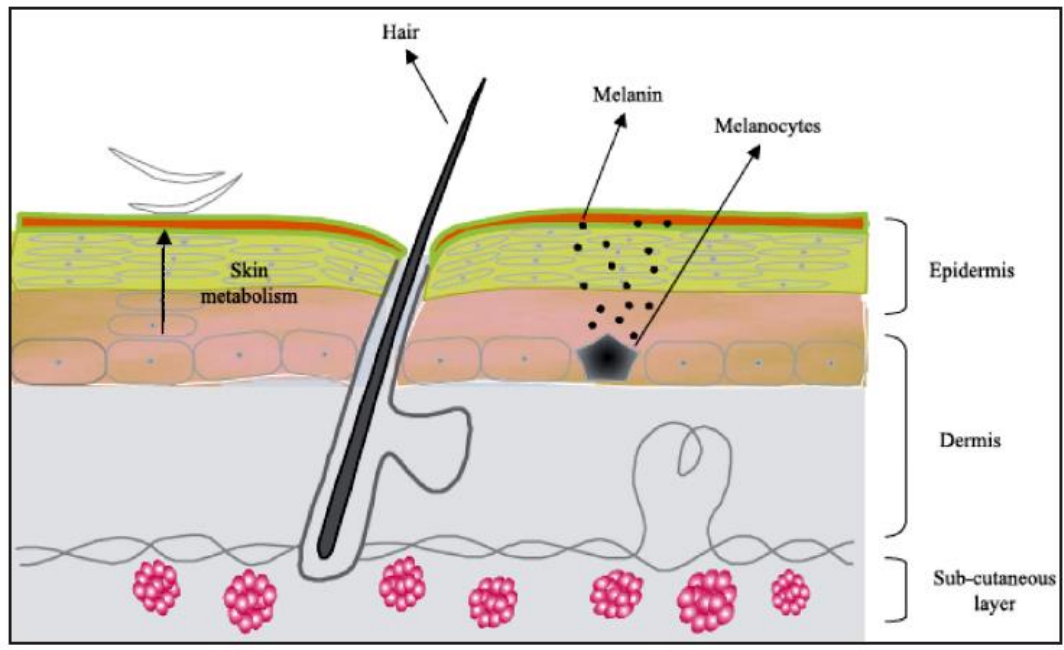

Gambar 3. Gambaran Kulit yang memiliki tiga lapisan utama yaitu epidermis, dermis dan subkutan, hasil pigmentasi yang terlihat dari sintesis dan distribusi melanin dalam melanosit di lapisan dermis kulit ${ }^{11}$ 


\section{Mekanisme Whitening Agent}

Efek whitening dapat dicapai dengan mengganggu sebelum, selama atau setelah sintesis melanin. Karena tirosin adalah enzim yang sangat penting dalam proses melanogenesis, itu juga memainkan peran kunci dalam proses ini. Oleh karena itu, ini adalah target dalam pemutihan kulit. Selain itu juga dapat terjadi dengan memodulasi MC1R, menghambat ROS, penghambatan transfer melanosom atau dengan meningkatkan penyebaran melanin ${ }^{20}$. Contoh whitening agent disajikan pada Tabel 1 dan gambaran umum mekanismenya disajikan dalam Tabel 2.

Tabel 1. Contoh Whitening Agent ${ }^{21}$

\begin{tabular}{|c|c|c|}
\hline Golongan & Agen Pemutih & Singkatan \\
\hline \multirow[t]{6}{*}{ Turunan Hydroquinon } & Hydroquinone & $\mathrm{HQ}$ \\
\hline & Hydroquinone monomethyl ether & HQMM \\
\hline & Hydroquinone monoethyl ether & HQME \\
\hline & Hydroquinone monobenzyl ether & HQMB \\
\hline & Resorchinol & $\mathrm{RS}$ \\
\hline & Arbutin & ARB \\
\hline \multirow[t]{2}{*}{ Turunan Merkuri } & Mercury chloride & \\
\hline & Mercury lodide & \\
\hline \multirow[t]{2}{*}{ Turunan Retinoids } & Retinoic acid (tretinoin) & RA \\
\hline & Retnyl Palmitate & $\mathrm{RP}$ \\
\hline \multirow[t]{6}{*}{ Turunan Asam Askorbat } & Ascorbic Acid & AA \\
\hline & Ascorbyl Palmitate & $\mathrm{AP}$ \\
\hline & Ascorbyl dipalmitate & ADP \\
\hline & Ascorbyl Stearate & AS \\
\hline & $\begin{array}{l}\text { Magnesium or Sodium Ascorbyl } \\
\text { Phospate }\end{array}$ & MAP, SAP \\
\hline & Ascorbyl Glucoside & $\mathrm{AG}$ \\
\hline \multirow[t]{4}{*}{ Lainnya } & Kojic Acid & $\mathrm{KA}$ \\
\hline & Kojic Dipalmitate & KDP \\
\hline & Azelaic Acid & AZA \\
\hline & Niacinamide & $\mathrm{NC}$ \\
\hline
\end{tabular}


Tabel 2. Perbedaan Mekanisme Senyawa Untuk Depigmentasi ${ }^{20,22}$

\begin{tabular}{|c|c|}
\hline Mekanisme & Senyawa \\
\hline $\begin{array}{l}\text { MenghambatTranskripsi } \\
\text { Tirosinase }\end{array}$ & $\begin{array}{l}\text { Tretinoin, } \quad \text { glucosamine, } \\
\text { retinaldehyde, } \mathrm{N} \text {-acetyl glucosamine }\end{array}$ \\
\hline Menghambat Tirosinase & $\begin{array}{l}\text { Hydroquinone, mequinol, arbutin, } \\
\text { azelaic acid, retinoids, lactic acid, } \\
\text { glycolic acid, liquiritin, kojic acid }\end{array}$ \\
\hline Pergantian Epidermal & $\begin{array}{l}\text { Ascorbic acid, thioctic acid, retinoids, } \\
\text { lactic acid, glycolic acid, liquiritin, } \\
\text { salicylic acid, Alpha Hydroxy Acids }\end{array}$ \\
\hline $\begin{array}{l}\text { Menghambat } \\
\text { Melanosom }\end{array}$ & Linoleic acid, Nicotinamide \\
\hline Anti Inflamasi & Niacinamide, soy milk \\
\hline Agen Penangkap Radikal Bebas & $\begin{array}{l}\text { Alpha lipoic acid, ascorbic acid, } \\
\text { glycyrrhetinic acid }\end{array}$ \\
\hline Memodulaci MCR1 & Corticosteroid \\
\hline
\end{tabular}

\section{Hydroquinone}

Bahan aktif paling populer yang secara tradisional digunakan dalam jenis produk kosmetik pemutih adalah hydroquinone ( $\mathrm{HQ})$. Hydroquinone adalah senyawa hidroksifenolik yang menghambat sintesis melanin dengan menghambat enzim tirosinase, selain itu juga dengan mengganggu pembentukan atau degradasi melanosom dan dengan menghambat sintesis DNA dan RNA dalam melanosit ${ }^{23}$.

Namun, HQ menyebabkan permasalahan dermatologis seperti dermatitis, ochronosis, depigmentasi permanen dan efek samping karsinogenik ${ }^{22,24}$. Pada konsentrasi mulai dari $2 \%$ hingga $5 \%$, dapat menyebabkan beberapa efek yang tidak diinginkan seperti iritasi dermatitis, dermatitis kontak, pigmentasi pascainflamasi, ochronosis, dan perubahan warna kuku²5.

Hydroquinone mono methyl ether (MEHQ), yang dikenal sebagai 4-hydroxyanisole atau mequinol sifatnya kurang mengiritasi daripada hidrokuinon dan tidak bersifat sitotoksik terhadap melanosit manusia. Monobenzylether of hydroquinone (MBEHQ) adalah agen yang kuat dalam proses melanogenesis, tetapi penggunaannya terbatas karena menghancurkan melanosit bahkan di bagian yang tidak terpapar ${ }^{25,26}$. Oleh karena itu, agen ini secara klinis digunakan untuk mengobati pasien vitiligo yang sangat terpengaruh dan tidak responsif terhadap terapi repigmentasi. MBEHQ digunakan untuk menghasilkan warna kulit yang rata dan efektivitasnya telah ditunjukkan dalam beberapa uji klinis dan studi kasus ${ }^{27-29}$. 
Dalam kontak dengan kulit, MBEHQ dimetabolisme oleh tirosinase dan menghasilkan quinone-haptens, yang terakhir menginduksi kehancuran nekrotik melanosit dan meningkatkan respon imunologi yang disebabkan oleh quininehaptens, yang bertanggung jawab untuk depigmentasi umum. Karena depigmentasi bersifat ireversibel, MBEHQ tidak dapat digunakan dengan aman dalam kosmetik.

\section{Arbutin}

Arbutin (ARB), yang merupakan turunan $\mathrm{HQ}$ alami paling populer yang diterima oleh industri kosmetik dari pada senyawa induknya, karena kurang berbahaya ${ }^{17,24}$. Bahkan, ditambahkan ke kosmetik sebagai senyawa murni atau melalui ekstrak dari Arctostaphylos uva-ursi dan Arbutus unedo21.

Arbutin adalah hidrokuinon glikosida dengan 2 isoform, 4-hydroxyphenyl glucopyranoside dan 4-hydroxyphenylglucopyranoside. Arbutin diperoleh dari berbagai tanaman di Indonesia Ericaceae (bearberry, pohon stroberi, huckleberry, heather), Saxifragaceae, Asteraceae, Rosaceae, Keluarga Lamiaceae, dan Apiaceae 30,31 . Turunan sintetiknya, deoxyarbutin (4- (tetrahydro-2H-pyran-2-yl) oxy] fenol) memiliki keuntungan dibandingkan arbutin yaitu lebih efektif dan sitotoksik yang rendah ${ }^{32}$.

Arbutin banyak digunakan sebagai agen depigmentasi dengan menghambat aktivitas tirosinase karena kesamaan struktural dengan substrat tirosin ${ }^{33}$. Arbutin menghambat reaksi keduanya yang dikatalisis oleh tirosinase, hidroksilasi L-tirosin dan oksidasi L-DOPA ${ }^{10}$. Arbutin dianggap aman bagi konsumen pada konsentrasi hingga $2 \%$ dalam produk kosmetik ${ }^{30}$. Namun, partikel nano formulasi dengan konsentrasi $10 \%$ b / b dan arbutin $15 \%$ b / b telah dipatenkan ${ }^{34}$.

Hasil penelitian $\mathrm{Hu}$ et al., ${ }^{35}$ menunjukkan bahwa hydroquinone dan dua turunan glukosida, arbutin dan Deoxyarbutin (D-ARB),menunjukkan kesamaan penghambatan aktivitas tirosinase. Tidak ada perubahan ekspresi protein tirosinase dalam sel yang diberi perlakuan dengan arbutin atau hidrokuinon yang terdeteksi dalam uji Western blotting, tetapi regulasi penurunan ekspresi tirosinase yang signifikan ditemukan pada sel yang diberi perlakuan dengan D-ARB. Kesimpulannya, penelitian ini menunjukkan bahwa D-ARB, sebuah turunan baru dari hydroquinone glucoside, yang merupakan kandidat whitening agentdengan manfaat penghambatan tirosinase kuat, penetrasi kulit yang efektif, lebih sedikit sitotoksisitas dan bahkan aktivitas antioksidan sampai batas tertentu.

\section{Retinoid Acid / Tretinoin}

Tretinoin adalah bentuk asam karboksilat dari vitamin A (retinol) ${ }^{36}$. Mekanisme kerja tretinoin melibatkan penghambatan induksi tirosinase, dispersi butiran pigmen keratinosit, penghambatan transfer melanin dan percepatan pergantian epiderma| ${ }^{37,38}$. Namun, aplikasi tretinoin disertai dengan iritasi kulit yang tergantung 
pada dosis tertentu. Penggunaan tretinoin dibatasi oleh kelarutan air yang rendah dan ketidakstabilan yang tinggi di udara, cahaya dan panas. Produk degradasi yang dihasilkan adalah isomer dari tretinoin ${ }^{39}$.

\section{Ascorbic Acid(Vitamin C)}

Beberapa turunan dari vitamin $\mathrm{C}$ telah menunjukkan efek pengurangan produksi melanin dan meningkatkan kecerahan kulit ketika diaplikasikan secara topikal. Turunan dari vitamin C ini seperti $L$-ascorbic acid, magnesium ascorbyl phosphate dan sodium ascorbylphosphate. Biasanya zat- zat ini digunakan masing - masing ataupun kombinasi dan menurunkan hiperaktif dari melanosit sehingga kulit menjadi lebih cerah.

Asam L-askorbat adalah bentuk vitamin $\mathrm{C}$ yang aktif secara biologis dan bermanfaat ${ }^{40}$, larut dan berfungsi dalam kompartemen sel yang berair selain dari regenerasi vitamin $\mathrm{E}$ dapat meningkatkan sintesis kolagen ${ }^{41}$, dan memberikan perlindungan antioksidan yang bertindak sebagai zat pereduksi yang memblokir reaksi berantai oksidasi dari produksi melanin di berbagai titik. Penghambatan melanin ini menghasilkan kulit yang lebih terang dan cerah hanya dalam beberapa minggu. Asam L-askorbat dilaporkan memiliki keamanan dan efisiensi yang sangat baik dan tidak beracun dengan iritasi yang minim. Namun zat ini harus diformulasikan pada $\mathrm{pH}$ kurang dari 3,5 untuk berpenetrasi ke dalam kulit dan konsentrasi maksimum untuk penyerapan per kulit yang optimal dilaporkan sebesar $20 \% 42$. Asam L-askorbat juga digunakan secara topikal karena kemampuannya mengurangi keriput dengan meningkatkan sintesis kolagen dan aktivitas depigmenting kulitnya ${ }^{43}$. Karena efek yang menguntungkan ini, asam $\mathrm{L}$ - askorbat telah lama digunakan dalam farmasi dan formulasi kosmetik ${ }^{44}$.

Penggunaan asam askorbat dalam produk kosmetik dan farmasi terbatas karena stabilitasnya yang rendah. Di bawah kondisi aerobik teroksidasi secara reversibel menjadi I-dehydro asam askorbat, yang secara irreversibel terdegradasi menjadi asam oksalat ${ }^{45}$. Untuk mengatasi masalah stabilitas ini, turunan vitamin $\mathrm{C}$, beberapa ester seperti natrium ascorbyl phosphate dan magnesium ascorbyl phosphate, telah disintesis dan memiliki aksi mirip dengan asam askorbat tetapi dengan peningkatanstabilitas kimia.

Magnesium-L-askorbat-2-fosfat(MAP) adalah bentuk yang paling populer dan stabil dan mudah diserap ke dalam kulit karena bersifat lipofilik. MAP memiliki efek menghidrasi dan mengurangi kehilangan air dari trans-epidermal ${ }^{40}$. MAP adalah penangkap radikal bebas dengan fotoprotektif dan meningkatkan produksi kolagen. Hal ini diketahui dapat menekan pembentukan melanin ketika digunakan pada level $10 \%$ dalam krim. la juga dikenal memiliki efek perlindungan terhadap kerusakan kulit yang disebabkan oleh radiasi UVB $0,5-25 \%$ dari berat MAP dalam krim pemutih kulit dilaporkan mengurangi iritasi kulit ${ }^{41}$. 


\section{Kojic Acid}

Kojic Acid (KA) (nama 'asam kojic' berasal dari "Koji") adalah bahan kimia Asam Kojic (5-hydroxy - 2- hydroxyl methy-4-pyrone adalah produk jamur hidrofilik yang berasal dari spesies tertentu Acetobacter, Aspergillus dan Penicillium. Zat ini diperoleh dari berbagai jenis jamur seperti A. flavus, A. oryzae, A. tamarii, dan A. parasiticus dan juga diproduksi dari fermentasi beberapa makanan Asia (mis. kecap dan anggur beras), yang bertindak sebagai primer untuk jamur atau inokulum ${ }^{46-49}$.

Kojic Acid ini mengurangi hiperpigmentasi dengan menghambat produksi tirosinase bebas dan juga antioksidan kuat ${ }^{50}$. Mekanisme KA dapat dilihat pada gambar 3 . KA digunakan dari $1-4 \%$. Aktivitas penghambatannya dilakukan oleh penghambatan aktivitas katekolase tirosinase, yang merupakan enzim esensial dalam biosintesis pigmen melanin ${ }^{51}$.

Mirip dengan whitening agent kulit lainnya seperti $\mathrm{HQ}$ dan arbutin, KA menghambat enzim tyrosinase, terutama disebabkan karena KA dapat mengkelatkan tembaga ${ }^{46,47,52}$. Telah dilaporkan KA memiliki potensi sensitisasi yang tinggi dan dengan demikian dapat menyebabkan dermatitis kontak iritan ${ }^{53}$. Iritasi ini dapat dikurangi dengan menggabungkan nya dengan kortikosteroid topikal. Data mendukung keamanan penggunaan KA pada konsentrasi $2 \%$ dalam kosmetik ${ }^{54}$.

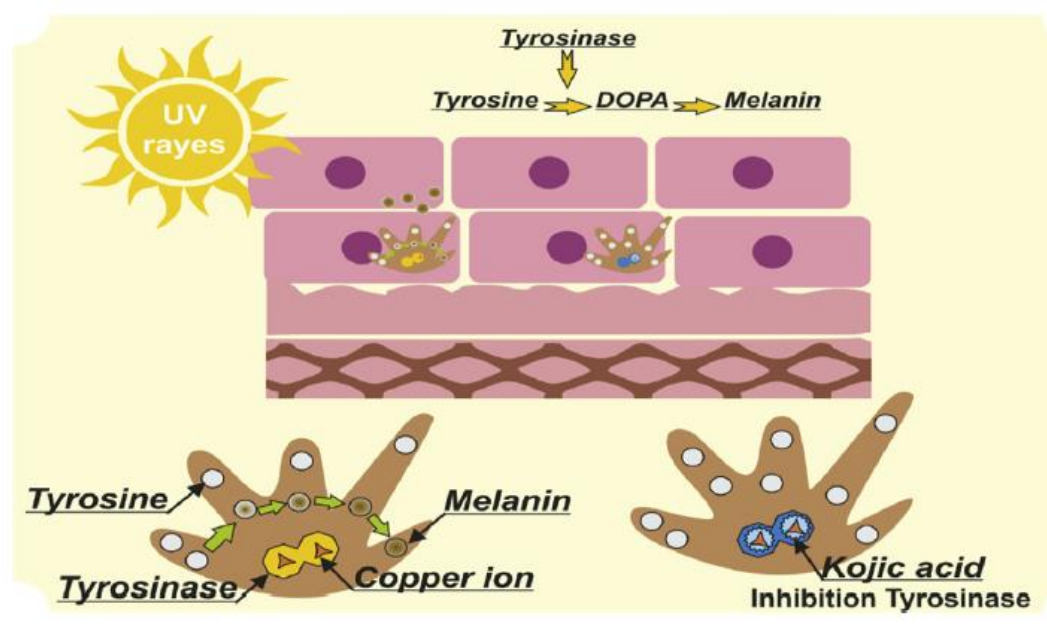

Gambar 4. Mekanisme Penghambatan Tyrosinase oleh Kojic Acid dalam Biosintesis Melanin 55

Beberapa penelitian dilakukan untuk mengevaluasi mekanisme depigmentasi dan keamanan kojic acid. Hasilnya menunjukkan konsentrasi untuk sediaan topikal KA adalah $1 \%$ atau kurang karena dalam rentang ini $\mathrm{KA}$ menunjukkan sifat yang efektif dan aman. Secara klinis penelitian telah menunjukkan efektivitas terapi krim KA 1\% selama 6 bulan pada pasien melasma foto-hipersensitif. Pasien melasma yang telah menggunakan krim KA 1\% selama 2 tahun dan tidak ada efek samping atau reaksi merugikan yang diamati55. 
Saat ini, agen depigmentasi baru seperti KA dikenal sebagai produk komersial cosmeceutical dan senyawa lainnya dapat ditawarkan di masa depan Di banyak penelitian, berbagai turunan dari KA seperti KA ester, KA dipalmitat dan KA etil fosfonat dengan aldehida dilaporkan lebih efektif daripada $K A^{55}$.

Beberapa reaksi dan kerugian yang merugikan terkait dengan KA di aplikasi kosmetik yaitu dermatitis kontak (terutama untuk kulit sensitif) adalah efek samping utama KA yang disertai iritasi, ruam, kulit meradang, gatal, dan nyeri.Efek samping ini dapat diamati dengan konsentrasi lebih tinggi lebih dari 1\% KA. Reaksi merugikan lainnya dapat muncul dalam penggunaan KA jangka panjang, seperti kulit terbakar pada bagian sensitif kulit. KA juga dapat menyebabkan kanker kulit pada kulit yang rusak. Tapi selanjutnya diperlukan studi untuk mengidentifikasi potensi manfaat atau resiko KA lainnya ${ }^{55}$.

Kojic acid sensitif terhadap cahaya dan panas dan cenderung teroksidasi dari waktu ke waktu. Terlebih lagi, Kojic acidmengekelat dengan ion logam menyebabkan perubahan warna (dari putih menjadi coklat atau kuning). Oleh karena itu, enkapsulasi KA dapat meningkatkan stabilitas fisiko-kimianya ${ }^{56}$.

\section{Azelaic Acid}

Asam azelaic adalah senyawa rantai lurus alami dari asam dicarboxylic jenuh yang diproduksi oleh ragi, Pityrosporum ovale, dan Malassezia furfur. Jamur yang menghasilkan lipoksigenase yang mampu bekerja pada asam lemak tak jenuh di permukaan kulit. Dalam kultur, jamur ini mampu mengoksidasi asam oleat menjadi asam azelaic ${ }^{57}$. Asam azelaic adalah kompetitif yang agak lemah terhadap inhibitor tirosinase. Sebagai tambahan, ia memiliki antiproliferatif dan efek sitotoksik pada melanosit ${ }^{11}$.

Asam azelaic tidak dapat menginduksi depigmentasi pada kulit yang berpigmen normal, sehingga azelaic acid lebih selektif antiproliferatif dan aksi sitotoksik pada melanosit abnormal. Telah di laporkan zat ini menjadi efektif dalam hypermelanosis disebabkan secara fisik dan agen kimia, serta gangguan kulit lainnya ditandai dengan proliferasi abnormal melanosit. Selain itu masalah dalam penggunaan asam azelaic adalah respon terapi yang agak lambat ${ }^{19}$. Sebuah studi klinis terkontrol dilakukan pada 52 wanita dengan kulit gelap atau berpigmen (fototipe) IV sampai VI) yang menderita melasma menunjukkan keunggulan krim yang mengandung $20 \%$ asam azelaic. Para wanita menemukan bahwa kulit mereka lebih halus. Namun beberapa efek yang tidak diinginkan (terbakar, kesemutan) dilaporkan. Tampaknya formulasi yang mengandung $20 \%$ asam azelaic setara dengan hidrokuinon $4 \%$ secara in vivo ${ }^{57}$.

Dalam studi 6 bulan oleh Sarkarpada 132 wanita Asia dengan melasma, rata-rata 4 tahun pengobatan dengan asam azelaic menyebabkan keduanya lebih cerah, lesi berpigmen dan pengurangan ukuran lesi. 


\section{Niacinamide}

Niacinamide (NA) adalah senyawa alami yang banyak ditemukan pada tanaman dan tersedia secara komersial sebagai zat pemutih kulit pada produk kosmetik di Indonesia. NA mengurangi melanogenesis di kulit dengan menghambat transfer melanosome dari melanosit ke sekitar keratinosit. Terlebih lagi, NA melindungi kulit dari ROS dan berfungsi sebagai pembawa utama pada kulit, mencegah hilangnya kelembaban dengan meningkatkan produksi ceramides dan asam lemak. NA sangat stabil di bawah paparan radiasi UV, panas, oksigen, asam, dan basa ${ }^{58}$.

Senyawa hidrofilik seperti NA hampir sulit ditembus melalui kulit dan senyawa lipofilik juga tidak mudah menyerap. Jadi, NA, yang merupakan senyawa yang larut dalam air, tidak mudah menembus ke dalam stratum korneum meskipun memiliki berat molekul yang rendah ${ }^{59}$.

Selain itu, NA bersifat iritan karena asam nikotinat dalam NA. Karena itu, kami telah fokus pada cara-cara untuk memperbaiki kulit NA permeabilitas dan mencegah efek iritasi. Niacinamide atau Nicotinamide (3-pyridine-carboxamide) adalah bentuk aktif vitamin B3. NA mengganggu interaksi antara keratinosit dan melanosit sehingga menghambat melanogenesis. Ini memodulasi protease reseptor (PAR-2) yang terlibat dalam transfer melanosom ke sekitar keratinosid dari melanosit. $2 \%$ NA dalam formulasi telah terbukti mengurangi hiperpigmentasi sehingga meningkatkan warna kulit yang merata dalam empat minggu ${ }^{60}$.

Dalam uji klinis, 5\% niacinamide memberi 35\% -68\% inhibisi melanosome, hiperpigmentasi yang menurun secara signifikan dan peningkatan kecerahan kulit setelah 4 minggu penggunaan ${ }^{61}$. Secara In vitro molekul niacinamide mempengaruhi viabilitas melanosit dan keratinosit, mengurangi lesi hiperpigmentasi dan mampu menghambat transfer melanosome dan menginduksi pencerah kulit62. Adapun skema ilustrasi mekanisme dari beberapa whitening agent dapat dilihat pada gambar 5 .

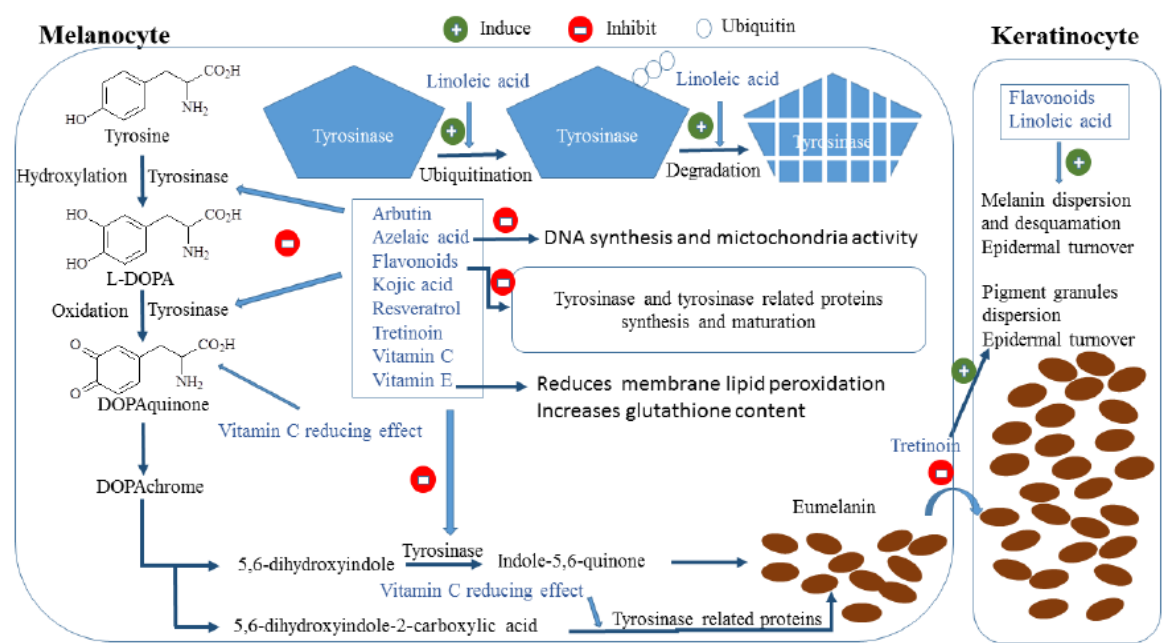

Gambar 5. Skema llustrasi Mekanisme Aksi dari Whitening Agent63 
Whitening Agent dari Bahan Alam

\section{Bunga Temulawak(Curcuma xanthorrhiza)}

Hasil penelitian Batubara et al., ${ }^{64}$ menunjukkan fraksi ekstrak etanol bunga temulawak adalah yang paling potensial sebagai inhibitor tirosinase karena memiliki nilai $I_{50}$ terendah dibandingkan ekstrak lainnya yaitu sebesar $0,97 \mathrm{mg} / \mathrm{mL}$ pada reaksi reaksi monophenolase dan $1,7 \mathrm{mg} / \mathrm{mL}$ pada reaksi diphenolase, senyawa aktif yang terkandung adalah golongan flavonoid yaitu auron.

\section{Teripang (Holothuroidea)}

Hasil penelitian menunjukkan adanya potensi whitening agent kulit dari bahan laut yaitu teripang.Aktivitas penghambatan tirosinasae fraksi> $50 \mathrm{kDa}$ adalah 20,54\% $50,84 \%$. Secara khusus, aktivitas penghambatan tirosinase $50,84 \%$ yang hampir sama dengan aktivitas penghambatan asam askorbat sebesar $69,95 \%$. Sehigga fraksi glikoprotein teripang dengan konsentrasi $>50 \mathrm{kDa}(10 \mathrm{mg} / \mathrm{mL})$ dapat berfungsi sebagai bahan kosmetik fungsional untuk memutihkan kulit 65 .

\section{Cendana Merah(Pterocarpus santalinus)}

Kandungan utamanya adalah santalin, hasil penelitian in vitro menunjukkan nilai $\mathrm{IC}_{50}$ dari santalin adalah15,21 $\pm 0,326 \mathrm{mM}$, santalin menghambat melanogenesismelalui regulasi MITF (Microphthalmia-Associated Transcription Factor)tirosinase, TRP1(Tyrosinase Related Protein-1) dan TRP-2 (Tyrosinase Related Protein-2)tanpa efek sitotoksik terhadap sel melanoma B16F0.Oleh karena itu, hasil menunjukkan bahwa santalin memiliki aktivitas antityrosinase, yang dapat digunakan sebagai agenpemutih yang aman di bidang kosmetik ${ }^{66}$.

\section{Persik (Prunus persica)}

Di antara tanaman yang diuji, bunga Prunus persica menunjukkan aktivitas penghambatanmelanogenesis paling kuat yaitu sebesar $52 \%$ dengan konsentrasi $500 \mu \mathrm{g} / \mathrm{mL}$. Selain itu, P. persica juga menunjukkanpenekanan melanogenesis sel melanoma tikus B16. Hal ini karena adanya kandungan afzelin (3-O- $\alpha-L-$ rhamnosylkaempferol) flavanon, dan naringenin. Mekanisme efek antimelanogenesis dari dua senyawa ini adalahpenekanan ekspresi protein tirosinase, yang dikendalikan oleh penghambatan fosforilasi p38MAPK(p38 Mitogen-Activated Protein Kinases). Temuan ini menunjukkan bahwa senyawa ini bisa menjadi kandidat target molekul baru sebagai whitening agent 67 . 


\section{Merbau Darat (Intsia palembanica)}

Telah dilakukasi isolasi flavonoid dari tanaman I. Palembanica. Hasil isolasinya yaitu dari senyawa robidanol yang memiliki aktivitas penghambatan terhadap enzim tirosinase dengan $\mathrm{IC}_{50}$ pada monophenolase sebesar $8,7 \mu \mathrm{M}$, diphenolase $26,6 \mu \mathrm{M}$ dan menghambat sintesis melanin sebesar $46,2 \%$ sehingga robidanol dapat digunakan sebagai whitening agent ${ }^{68}$.

\section{Pengembangan Teknologi Formulasi dari Whitening Agent}

\section{Liposom Flexibel Niacinamide}

Hasil penelitian yang dilakukan untuk mengevaluasi formulasi dan karakteristik liposom fleksibel dari $2 \%$ Niacinamide yang terdiri dari membran lipid biokompatibel dengan dipotassium glycyrrhizate (DPG) menunjukkan peningkatan aktivitas pemutihan kulit dan memiliki kestabilan yang baik, sehingga liposome dapat menjadi sistem penghantaran baru untuk meningkatkan efektifitas permeasi transdermal suatu zat pemutih kulit 58 .

\section{Mikroemulsi Hesperetin}

Mikroemulsi merupakan pembawa potensial untuk sistem pengiriman transdermal. Mikroemulsi yang berbahan hesperetin menunjukkan peningkatan permeasi secara in vitro jika dibandingkan dengan airdan bentuk sediaan suspensi isopropyl myristate (IPM) dari hesperetin. Sebagai perbandingan, efek co-surfactant pada kapasitas permeasi obat, propilen glikol menunjukkan laju permeasi tertinggi, diikutioleh etanol, gliserol dan polietilen glikol (PEG 400). Agen tabir surya padimate $O$, sebagai enhancer transdermalbisa meningkatkan tingkat permeasi hesperetin. Dalam kasus studi in vivo, hesperetinmikroemulsi menunjukkan efek pemutihan topikal yang signifikan dan berkurangnya iritasi kulitdibandingkan dengan kelompok kontrol negatif, yang menunjukkan bahwa mikroemulsi hesperetin dapat digunakan sebagaiwhitening agentdan menghasilkan sediaan yang lebih efektif69.

\section{Solid Lipid Nanoparticle(SLN)}

Hasil penelitian menunjukkan bahwa formulasi topikal krim SLN dengan QNT318(hydrazinecarbothioamide) merupakan pembawa yang tepat untuk whitening agent kulit70. Penelitian lain menunjukkan kelarutan 6-methyl-3-phenethyl-3,4dihydro-1H-quinazoline-2-thione(JSH18) melalui formulasi SLNmeningkat 8 kali lipat dibandingkan dengan JSH18. Jumlah yang dipertahankan JSH18dalam bentuk SLNs ke kulit tikus meningkat. Secara bersama-sama, penelitian ini menunjukkan formulasi topikalseperti krim termasuk SLN mungkin merupakanpembawa yang tepat untuk formulasi whitening agent ${ }^{71}$. 


\section{Polimeric Nanoparticle}

AP736(adamantyl benzylbenzamide derivative)adalah whitening agent baru yang dilaporkan menunjukkan anti-melanogenesis danaktivitas penghambatan tirosinase. Namun, memformulasikannya dalam produk topikal sulit karenaAP736 tidak larut dalam air maupun dalam minyak. Dilakukan penelitian untuk mengembangkan sistem penghantaran topikal dari AP736 yang tidak stabil secara fisik dengan menggunakan hansen solubility parametersdan nanopartikel. Hasilnya ukuran partikel rata-rata dari $50 \mathrm{~nm}$ hingga $200 \mathrm{~nm}$. Sebagian besarmenunjukkan enkapsulasi yang baikdengan entrapment eficiencyhingga $90 \%$ dan stabil selama pengujian 4 minggu, sehingga dapat disimpulkan polimeric nanoparticlemerupakan pembawa yang efektifuntuk aplikasi topikal AP736 sebagai whitening agent ${ }^{72}$.

\section{Kesimpulan}

Melanin adalah pigmen yang menentukan warna kulit dan disintesis menggunakan enzim tirosinase sehingga enzim ini menjadi target inhibisi utama dari whitening agent, contohnya yaitu hydroquinone, ascorbic acid, kojic acid, arbutin, niacinamide, retinoid, azelaic acid. Whitening agent juga dapat berasal dari bahan alam yang umumnya digunakanuntuk meminimalkan efek sampingpada kulit seperti temulawak, cendana, purnus, dan teripang. Modifikasi sistem penghantaran untuk mengoptimalkan efeknya dapat dilakukan menggunakan sistem nanopartikel, SLN, mikroemulsi dan liposom.

\section{Daftar Pustaka}

1. Adhikari A, Devkota HP, Takano A, Masuda K, Nakane T, Basnet P, et al. Screening of Nepalese crude drugs traditionally used to treat hyperpigmentation: In vitro tyrosinase inhibition. Int J Cosmet Sci. 2008;30(5):353-60.

2. James W., Berger T., Elston D. Andrews. Diseases Of The Skin: Clinical Dermatology (10th ed.). Philadelphia: Elsevier Saunders; 2006.

3. Lewis KM, Robkin N, Gaska K, Njoki LC. Investigating Motivations for Women's Skin Bleaching in Tanzania. Psychol Women Q. 2011;35(1):29-37.

4. Murata K, Takahashi K, Nakamura H, Itoh K, Matsuda H. Search For Skin-Whitening Agent From Prunus Plants And The Molecular Targets In Melanogenesis Pathway Of Active Compounds. Nat Prod Commun. 2014;9(2):185-8.

5. Jeong HS, Gu GE, Jo AR, Bang JS, Yun HY, Baek KJ, et al. Baicalin-induced Akt activation decreases melanogenesis through downregulation of microphthalmiaassociated transcription factor and tyrosinase. European Journal Pharmacol. 2015;761:19-27.

6. Oh MJ, Abdul Hamid M, Ngadiran S, Seo YK, Sarmidi MR, Park CS. Ficus deltoidea Extract Exerted Anti-Melanogenic Activity By Preventing Tyrosinase Activity In Vitro And By Suppressing Tyrosinase Gene Expression In B16F1 Melanoma Cells. Archives Dermatological Research. 2011;303(3):161-70.

7. Briganti S, Ottaviani M, Picardo M. Chemical, Pharmacologic, And Physical Agents Causing Hypomelanoses. The Pigmentary System. Wiley-Blackwell, Oxford; 2006. 669. 
8. Simon JD, Peles D, Wakamatsu K, Ito S. Current Challenges In Understanding Melanogenesis: Bridging Chemistry, Biological Control, Morphology, And Function.Pigment Cell Melanoma Research. 2009;22(5):563-79.

9. Ito S. IFPCS Presidential Lecture: A Chemist's View Of Melanogenesis. Pigment Cell Research. 2003;16(3):230-6.

10. Hori I, Nihei KI, Kubo I. Structural Criteria For Depigmenting Mechanism Of Arbutin. Phytotheraphy Research. 2004;18(6):475-9.

11. Parvez S, Kang M, Chung H-S, Cho C, Moo CH, Shin M-K, et al. Survey and Mechanism of Skin Depigmenting and Lightening Agents. Phytotheraphy Research. 2006;20:921-34.

12. Costin GE, Hearing VJ. Human Skin Pigmentation: Melanocytes Modulate Skin Color In Response To Stress. Federation of American Societies for Experimental BiologyJournal. 2007;21(4):976-94.

13. Park HY, Kosmadaki M, Yaar M, Gilchrest BA. Cellular mechanisms regulating human melanogenesis. Cellular and Mollecular Life Science. 2009;66(9):1493-506.

14. Yamaguchi Y, Brenner M, Hearing VJ. The Regulation Of Skin Pigmentation. Journal Biology and Chemistry. 2007;282(38):27557-61.

15. Ito S, Wakamatsu K. Chemistry Of Mixed Melanogenesis - Pivotal Roles Of Dopaquinone. Photochem Photobiol. 2008;84(3):582-92.

16. Videira IF, Moura DFL, Magina S. Mechanisms Regulating Melanogenesis. The Journal Brazilian Annals of Dermatology. 2013;88(1):78-63.

17. Gillbro JM, Olsson MJ. The Melanogenesis And Mechanisms Of Skin-Lightening Agents - Existing And New Approaches. International Journal Cosmetics Science. 2011;33(3):210-21.

18. Aoki H, Moro O. Involvement Of Microphthalmia-Associated Transcription Factor (MITF) In Expression Of Human Melanocortin-1 Receptor (MC1R). Life Science. 2002;71(18):2171-9.

19. Francisco,SJC and Garcia, B.Enzymology of Melanin Formation. Wiley-Blackwell, New Jersey; 2006. 1248 p.

20. Desmedt B, Courselle P, Beer JO De, Rogiers V, Grosber M, Deconinck E, et al. Overview Of Skin Whitening Agents With An Insight Into The Illegal Cosmetic Market In Europe.Journal of the European Academy of Dermatology and Venereology. 2016;943-50.

21. Chisvert A, Benedé JL, Salvador A. Tanning and Whitening Agents in Cosmetics: Regulatory Aspects and Analytical Methods. Second Edi. Analysis of Cosmetic Products: Second Edition. Elsevier B.V.; 2018. 107-121.

22. Couteau C, Coiffard L. Overview of Skin Whitening Agents: Drugs and Cosmetic Products. Cosmetics. 2016;3(27):1-16.

23. Donsing P, Viyoch J. Thai Breadfruit's Heartwood Extract: A New Approach to Skin Whitening. SWU Science Journal. 2008;24(1):9-24.

24. Naidoo L, Khoza N, Dlova NC. A Fairer Face , a Fairer Tomorrow ? A Review of Skin Lighteners. Cosmetics. 2016;3(33):1-11.

25. Rendon M, Berneburg M, Arellano I, Picardo M. Treatment Of Melasma. Journal of American of Academy Dermatology. 2006;54(5) :272-81.

26. Halder RM, Nordlund JJ. Topical Treatment of Pigmentary Disorders. The Pigmentary System: Physiology and Pathophysiology, Second Edition. 2006. 
27. Rordam OM, Lenouvel EW, Maalo M. Successful Treatment Of Extensive Vitiligo With Monobenzone. Journal Clinical Aesthetic Dermatology. 2012;5(12):36-9.

28. Felsten LM, Alikhan A, Petronic-Rosic V. Vitiligo: A Comprehensive Overview: Part II: Treatment Options And Approach To Treatment.Journal American Academy Dermatology.2011;65(3):493-514.

29. AlGhamdi KM, Kumar A. Depigmentation Therapies For Normal Skin In Vitiligo Universalis. Journal European Academy Dermatology Venereology. 2011;25(7):749_ 57.

30. Degen GH, Bernauer U, Coenraads PJ, Dusinska M, Lilienblum W, Nielsen E, et al. Opinion of the Scientific Committee on Consumer Safety (SCCS) - Opinion on the safety of the use of $\beta$-arbutin in cosmetic products. Regul Toxicol Pharmacol. 2015;73(3):866-7.

31. Degen GH. Opinion of the Scientific Committee on Consumer safety (SCCS) Opinion On The Safety Of The Use Of A-Arbutin In Cosmetic Products. Regul Toxicol Pharmacol.2016;74:75-6.

32. Hamed SH, Sriwiriyanont P, DeLong MA, Visscher MO, Wickett RR, Boissy RE. Comparative Efficacy And Safety Of Deoxyarbutin, A New Tyrosinase- Inhibiting Agent. Journal Cosmetics Science. 2006;57(4):291-308.

33. Zhu W, Gao J. The Use of Botanical Extracts as Topical Skin-Lightening Agents for the Improvement of Skin Pigmentation Disorders. Journal Investigative Dermatology Sympton Proceedings. 2008;13(1):20-4.

34. Nanbu T. Whitening Cosmetic Composition Containing Arbutin Nanoparticles. United States Patent Application Publication.UD Pat 20090069253 A1. 2009;

35. Hu Z, Zhou Q, Lei T, Ding S, Xu S. Effects Of Hydroquinone And Its Glucoside Derivatives On Melanogenesis And Antioxidation: Biosafety As Skin Whitening Agents. Journal Dermatology Science.2009;55:179-84.

36. Akhavan A, Bershad S. Topical Acne Drugs: Review Of Clinical Properties, Systemic Exposure, And Safety.American Journal Clinical Dermatology. 2003;4(7):473-92.

37. Hassan A, Pharm HAM, Eltahir MM. Review on Skin Whitening Agents. 2010;13(1).

38.Zhu W, Zhang R, Draelos ZD, Thaman LA. Skin Lightening Agents. Cosmetic Formulation Of Skin Care Products. Cosmetic Science and Technology Series; Taylor and Francis Group LLC.: New York, NY, USA,; 2006. 205-218. p.

39. Sinico C, Manconi M, Peppi M, Lai F, Valenti D, Fadda AM. Liposomes As Carriers For Dermal Delivery Of Tretinoin: In Vitro Evaluation Of Drug Permeation And Vesicle-Skin Interaction. Journal Control Release. 2005;103(1):123-36.

40. Farris PK. Topical Vitamin C: A Useful Agent For Treating Photoaging And Other Dermatologic Conditions. Dermatologic Surgery. 2005;31(2):814-8.

41. Telang PS. Vitamin $\mathrm{C}$ in dermatology. Indian Dermatol Online Journal. 2013;4(2):143-7.

42. Burke KE. Interaction Of Vitamins C And E As Better Cosmeceuticals.Dermatologic Theraphy. 2007;20(5):314-21.

43. Zhai ZH, H. L. Maibach. Cosmetics and Toiletries. 2001;116(20).

44. Pinnell, S. D., H. Yang, M. Omar, N. M. Riviere, H. V. Debuys, L. C. Walker YW and ML. Dermatologic Surgery. 2001.Kleszczewska E. L-Ascorbic Acid-Clinical Use, Toxicity, Properties, Methods or Determination and Application in Chemical Analysis. Org Chem Rev. 2000;55(9):640-4. 
46. Ali S, Galgut J, Choudhary R. On the novel action of melanolysis by a leaf extract of Aloe vera and its active ingredient aloin, potent skin depigmenting agents. Planta Med. 2012;78(8):767-71.

47. Babitha S, Shin J-H, Kim E-K. Potential Skin Whitening Agents of Natural Origin from South Asian Region. J Soc Cosmet Sci Korea. 2009;35(1):1-9.

48. Kim K. Effect of ginseng and ginsenosides on melanogenesis and their mechanism of action. J Ginseng Res.2015;39(1):1-6.

49. Oyedeji FO, Akemu OCO-. Simultaneous Determination of Hydroquinone , Kojic Acid and L-Ascorbic Acid in Some Cosmetic Emulsions.International Journal of Science. 2017;3(8):46-52.

50. Lajis AFB, Hamid M, Ariff AB. Depigmenting effect of kojic acid esters in hyperpigmented B16F1 melanoma cells. J Biomed Biotechnol. 2012; 1-9.

51. Aytemir MD, Karakaya G. Kojic Acid Derivatives. Med Chem Drug Des. 2012;1.

52. Kim YC, Choi SY, Park EY. Anti-melanogenic effects of black, green, and white tea extracts on immortalized melanocytes. J Vet Sci. 2015;16(2):135-43.

53. Garcia-Gavin J, Gonzalez-Vilas D, Fernandez-Redondo V, Toribio J. Pigmented contact dermatitis due to kojic acid. A paradoxical side effect of a skin lightener. Contact Dermatitis. 2010;62(1):63-4.

54. Burnett CL, Bergfeld WF, Belsito D V., Hill RA, Klaassen CD, Liebler DC, et al. Final report of the safety assessment of kojic acid as used in cosmetics. International Journal of Toxicology. $2010 ; 29(4): 244-273$.

55. Saeedi M, Eslamifar M, Khezri K. Biomedicine \& Pharmacotherapy Kojic acid applications in cosmetic and pharmaceutical preparations. Biomed Pharmacother. 2019;110:582-93.

56. Gallarate M, Carlotti ME, Trotta M, Grande AE, Talarico C. Photostability of naturally occurring whitening agents in cosmetic microemulsions. $J$ Cosmet Sci. 2004;55(2):139-48.

57. Shin JW, Park KC. Current clinical use of depigmenting agents. Dermatologica Sin.2014;32(4):205-10.

58. Lee M, Lee K, Park M, Hyun S, Kahn S, Joo K, et al. Journal of Drug Delivery Science and Technology In vivo anti-melanogenesis activity and in vitro skin permeability of niacinamide-loaded fl exible liposomes (Bounsphere TM ). Journal of Drug Delivery Science and Technology.2016;31: 147 - 152.

59. Manela-Azulay M, Bagatin E. Cosmeceuticals vitamins. Clin Dermatol. 2009;27(5):469-74.

60. Rozman B, Gašperlin M. Stability of vitamins $C$ and $E$ in topical microemulsions for combined antioxidant therapy. Drug Deliv. 2007;14(4):235-45.

61. Hakozaki T, Minwalla L, Zhuang J, Chhoa M, Matsubara A, Miyamoto K, et al. The effect of niacinamide on reducing cutaneous pigmentation and suppression of melanosome transfer. Br J Dermatol. 2002;147(1):20-31.

62. Greatens A, Hakozaki T, Koshoffer A, Epstein H, Schwemberger S, Babcock G, et al. Effective inhibition of melanosome transfer to keratinocytes by lectins and niacinamide is reversible. Exp Dermatol. 2005;14(7):498-508.

63. Elissa Ephrem, Hamid Elaissari HG-G. Improvement of skin whitening agents efficiency through encapsulation: current state of knowledge. Int $J$ Pharm. 2017;526(1-2):50-68. 
64. Batubara I, Julita I, Darusman LK, Mahmoud A. Flower Bracts of Temulawak (Curcuma xanthorrhiza) for Skin Care: Anti-Acne and Whitening Agents. Procedia Chem 2015;14:216-24.

65. Kim SJ, Park SY, Hong SM, Kwon EH, Lee TK. Skin whitening and anti-corrugation activities of glycoprotein fractions from liquid extracts of boiled sea cucumber. Asian Pac J Trop Med. 2016;9(10):1002-6.

66. Hemachandran H, Amrita A, Mohan S, Gopalakrishnan M, Dakshinamurthy TK, Doss GP, et al. Functionality study of santalin as tyrosinase inhibitor: a potential depigmentation agent. Int J Biol Macromol. 2016;86: 383-389.

67. Murata K, Takahashi K, Nakamura H, Itoh K, Matsuda H. Search for Skin-whitening Agent from Prunus Plants and the Molecular Targets in Melanogenesis Pathway of Active Compounds. Natural Product Communication.2014;9(2):185-188.

68. Batubara I, Darusman L., Mitsunaga T, Aoki H, Rahminiwati M, Djauhari E, et al. Flavonoid from Intsia palembanica as Skin Whitening Agent. $J$ Biol Sci. $2011 ; 11(8): 475-80$.

69. Tsai Y, Lee K, Huang Y, Huang C. In vitro permeation and in vivo whitening effect of topical hesperetin microemulsion delivery system. International Journal of Pharmaceutics.2010;388:257-62.

70. Ki D, Jung H, Noh Y, Thanigaimalai P, Kim B, Shin S, et al. Preformulation and formulation of newly synthesized QNT3-18 for development of a skin whitening agent reformulation and formulation of newly synthesized QNT3-18 for development of a skin whitening agent. Drug Development and Industrial Pharmacy.2012;39(4): 526-533.

71. So JW, Kim S, Park J-S, Kim B-H, Jung S-H, Shin S-C, et al. Preparation and evaluation of solid lipid nanoparticles with JSH18 for skin-whitening efficacy. Pharm Dev Technol. 2010;15(4):415-20.

72. Shin HJ, Beak HS, II Kim S, Joo YH, Choi J. Development and evaluation of topical formulations for a novel skin whitening agent (AP736) using Hansen solubility parameters and PEG-PCL polymers. Int J Pharm. 2018;552(1-2):251-7. 